\title{
Teatro y tradición clásica a fines del s. XVI: Juan de la Cueva y la «tragedia del horror»
}

\author{
Antonio LÓPEZ FonSECA \\ Universidad Complutense de Madrid \\ alopezf@filol.ucm.es
}

Recibido: 21 de febrero de 2014

Aceptado: 8 de junio de 2014

\section{RESUMEN}

Este trabajo afronta el estudio de la tradición clásica en el teatro anterior a Lope, en general, y en Juan de la Cueva en particular. Tras un acercamiento al género a finales del s. XVI, el estudio se centra en la «tragedia del horror» y en uno de sus principales representantes: Juan de la Cueva. Una vez estudiados el autor y su obra, con especial atención a la importancia de la cultura clásica en su formación, se ofrece una selección de textos en la que se pone el acento en lo clásico como tema y como ornato.

Palabras clave: Tradición clásica. Teatro. Tragedia. Siglo XVI. Juan de la Cueva.

LóPEZ FonseCA, A., «Teatro y tradición clásica a fines del s. XVI: Juan de la Cueva y la «tragedia del horror»»», Cuad. Fil. Clás. Estud. Lat. 34.2 (2014) 283-313.

\section{Theatre and classical tradition at the end of the XVI ${ }^{\text {th }}$ century: Juan de la Cueva and the «tragedy of the horror»}

\begin{abstract}
This work deals with the study of the classical tradition in the theatre previous to Lope in a general way, focusing particularly on Juan de la Cueva. An approach to the literary genre at the end of XVI ${ }^{\text {th }}$ century is followed by a closer view to the «tragedy of the horror» and one of its more important authors: Juan de la Cueva. After studying the author and his work, paying special attention to the importance of the classical culture in his formation, a selection of texts is offered to emphasize the classic as topic and as ornament.
\end{abstract}

Keywords: Classical Tradition. Theatre. Tragedy. XVI ${ }^{\text {th }}$ century. Juan de la Cueva.

LóPEZ FonseCA, A., «Theatre and classical tradition at the end of the XVI ${ }^{\text {th }}$ century: Juan de la Cueva and the «tragedy of the horror»», Cuad. Fil. Clás. Estud. Lat. 34.2 (2014) 283-313.

SUMARIO: 1. Introducción. 2. El teatro prelopista: hacia un «nuevo» teatro para un «nuevo» público en un «nuevo» espacio. 3. El teatro de fines del s. XVI: la «tragedia del horror». 4. Juan de la Cueva (Sevilla, 1543 - Granada, 1612). 4.1. Aproximación a la figura y la obra. La cultura clásica en su formación y la tradición clásica en su obra. 4.2. La producción dramática y la reflexión sobre el arte dramático. 4.2.1. El Ejemplar poético. 4.2.2. Las comedias y tragedias. 4.2.3. Lo clásico como tema y como ornato. 5. A modo de conclusión. 6. Referencias bibliográficas. 


\section{INTRODUCCIÓN}

Lejos de ser un escritor de primer orden, las aportaciones teatrales de Juan de la Cueva contribuyeron a preparar la sazón del teatro nacional que estaba ya en esa época para producirse. Es, junto con Virués y Cervantes, el gran representante del esfuerzo por construir una tragedia nacional aparecido en el último tercio del siglo XVI. Y, excepción hecha del autor de la Numancia, es el dramaturgo más representativo de todos los que constituyen el grupo. No obstante ello, hay quienes le han negado la importancia que la crítica posterior le ha atribuido amparándose, básicamente, en el desequilibrio existente entre el valor intrínseco de su obra y el grado de difusión que alcanzó. Es el caso de Marcel Bataillon, con un artículo de 1935 que prendió la polémica, o de otros en fecha más reciente como Rinaldo Froldi (1968) y Othón Arróniz (1977). Por el contrario, otros como Edwin S. Morby (1940) y Bruce W. Wardropper (1955), en contestación a Bataillon, afirman la necesidad de examinar la obra de Juan de la Cueva al margen de toda comparación con el teatro que apareció después, el de la Comedia Nueva, insistiendo el segundo en que por su manera de servirse del romancero y de los temas populares supone un intento por conciliar humanismo y romancismo, y en esa convergencia de dos tendencias, la clásica y la popular, debe verse un drama perfectamente integral y representativo del pleno Renacimiento español.

\section{EL TEATRO PRELOPISTA: HACIA UN «NUEVO» TEATRO PARA UN «NUEVO» PÚBLICO EN UN «NUEVO» ESPACIO}

El reinado de Felipe II (1556-1598) es un período decisivo para la historia del teatro español. Si en su primera mitad fluctúa todavía en una encrucijada de tendencias, de viejas formas y de nuevas posibilidades, en sus últimos lustros encontrará el rumbo definitivo gracias al genio creador de Lope de Vega, que, fundiéndolas todas ellas, crea la fórmula de la dramática nacional del Siglo de Oro. En sentido lato, todo el teatro anterior a Lope podría llamarse «prelopista». Sin embargo, se designa bajo este nombre a la producción que inmediatamente le precede, esto es, la que sigue a la desaparición de Gil Vicente y Torres Naharro. Los cincuenta años que median entre la muerte de Gil Vicente y los comienzos de Lope constituyen un indeciso período de tanteos, que no aportarán valores permanentes ni conquistas definitivas, pero que supondrán el caldo de cultivo que cristalizará muy pronto en el gran teatro nacional.

En esa cadena textual que atraviesa el Quinientos van apareciendo ciertas experiencias dramáticas en las que la elaboración de tragedias, en plural, apunta como una preocupación dispersa y recurrente. Desde los ejercicios propios de la comedia humanística, con La Celestina al frente, hasta las traducciones y adaptaciones de autores clásicos hechas por Fernán Pérez de Oliva en los claustros salmantinos o por Lorenzo Palminero en la universidad valenciana, pasando por la práctica escénica de los colegios jesuíticos, hay una evidente preocupación por la elaboración de formas dramáticas trágicas (Hermenegildo 2003, pp.475-476). Por otra parte, hay una 
serie de ejercicios dramáticos llevados a cabo contando con la tradición trágica, la que arranca de la experiencia clásica griega o romana, la de Sófocles, Eurípides y, sobre todo, Séneca ${ }^{1}$. Y no puede olvidarse, como piedra fundamental del edificio, la utilización de la experiencia dramática llevada a cabo por los escritores italianos del Renacimiento.

Importantes factores de índole material van a contribuir también poderosamente a preparar la nueva dramática. Al mediar el reinado de Felipe II, se opera una transformación marcada por la instauración de un modo original de producción, por el surgimiento de un público cada vez más vasto, por la aparición de compañías de actores profesionales y, finalmente, por la edificación, en todas las grandes ciudades, de espacios de representación permanentes instalados en el recinto de los corrales. Al tiempo, la ampliación constante de un repertorio que, sin romper todos los lazos con el del período precedente, se diversifica en función de la demanda de un público también ampliado. Y a todo ello hay que sumar el advenimiento de una generación de poetas deseosos de escapar a las contingencias de un teatro de simple consumo, para elevarse hasta las cimas de un arte consciente de sus fines y sus apuestas. Resulta, pues, fundamental establecer diferencias entre los públicos a que iban destinados los distintos tipos de obras. Por una parte, había un público selecto, restringido, cerrado, «cautivo»-el cortesano, el colegial, el universitario, etc.-, que asistía a las representaciones dentro del marco que condicionaba su inserción social (Hermenegildo 1994, pp.17-18). En el sistema comunicativo que rige la fiesta teatral, al espectador cautivo el mensaje le llega marcado por una finalidad predeterminada. Con el advenimiento de Felipe II, al parecer un mediocre gustador de espectáculos, el mecenazgo principesco cayó en desuso y serán las cofradías y ayuntamientos quienes, para realzar el brillo de las fiestas litúrgicas, susciten y subvencionen representaciones sagradas y profanas. Habrá, pues, otro público, el «abierto». Los cenáculos aristocráticos de las primeras décadas del siglo XVI serán reemplazados por un público esencialmente urbano, de buena gana atraído por todas las manifestaciones de la fiesta. A esta evolución del público corresponde el surgimiento de todo un mundo de profesionales de la escena ${ }^{2}$. Ese público será el agente receptor de otra manera de utilizar el arte dramático, un destinatario de la comunicación teatral que no está definido a priori. Es el público que en el último tercio del XVI va a empezar a llenar los corrales. Mientras el espectador cautivo no supone la presencia de una resistencia deliberada a la recepción de los mensajes moralizadores, catequísticos, pedagógicos, el nuevo público al que hay que atraer antes de que la representación empiece se convierte en un adversario con el que el escritor, el actor, la compañía teatral, deben establecer una lucha dialéctica. Así, pueden distinguirse dos tendencias de creación trágica en

\footnotetext{
${ }^{1}$ No deja de ser curioso que los autores de tragedias, restauradores en cierto modo del arte clásico, ignoren el teatro cómico, dejándolo fuera de su tentativa de renovación. Así, en una época en que se traducía a Plauto y Terencio, se imita a Séneca.

${ }^{2}$ Para la aparición del teatro profesional, $c f$. A. Hermenegildo (1994, pp.155-198) y J.L. Canet Vallés (1997).
} 
el Quinientos: la del teatro universitario y colegial (García Soriano 1945), marcada por la presencia de un público cautivo; y la de los trágicos de fin de siglo, cuyas obras están destinadas a ser representadas ante un público abierto. El hecho es que, a fines de siglo, España tiene un número importante de directores de compañías, llamados autores de comedias. Y con la aparición del «corral», instalado en el patio interior de una casa, el repertorio profano dispondrá de un marco más adecuado para su desarrollo. Entre 1575 y 1585, Madrid, Sevilla, Valencia, Toledo, Valladolid, Barcelona, Zaragoza y Córdoba, se dotan de este tipo de edificio.

En esta transformación tuvo parte decisiva la presencia de compañías italianas con un influjo doble. De un lado como proveedoras de un espectáculo abierto que llegaba a públicos más amplios; de otro, por sus temas. El teatro italiano de la época puede definirse, en conjunto, como una dramática de intriga, más preocupada en mantener el interés a base de lances novelescos, de sucesos extraordinarios, de situaciones imprevistas, de enredos que se resuelven de la manera más inesperada. Ello explica el deseo de imitar ese teatro con una corriente dramática basada en la imitación de la comedia «novelesca» italiana, es decir, en el predominio de la acción sobre el análisis de caracteres y la verosimilitud.

Es una época, pues, de encrucijada que marca diversas tendencias dramáticas. El teatro religioso prosigue con variadas orientaciones; por su parte, el profano se escinde en tres corrientes principales: la clasicista, que pretende arraigar en nuestra literatura una dramática calcada sobre los grandes maestros del teatro grecolatino; la de influencia italiana, inspirada en la especie de teatro mencionada; y una tercera que podría denominarse de orientación nacional por sus temas, pero que sigue vaciándose todavía prácticamente dentro de los moldes clasicistas, grupo este último en el que se incluye a Juan de la Cueva.

\section{EL TEATRO DE FINES DEL S. XVI: LA «TRAGEDIA DEL HORROR»}

En términos generales, se ha considerado el siglo XVI, hasta la llegada a la escena de Lope de Vega, como una etapa difícil para el drama, caracterizada por una serie de búsquedas, fracasos y logros que van preparando el terreno para la creación en el siglo XVII de la comedia española ${ }^{3}$. Además del teatro universitario y del surgimiento en la segunda mitad de siglo de un teatro de colegio, principalmente en los centros de la Compañía de Jesús, en el último tercio de siglo hay que destacar el intento de crear una tragedia española por un grupo de autores a los que Ruiz Ramón (2000) reúne bajo el epígrafe de «generación de los trágicos» y Hermenegildo (1973) en el de «tragedia del horror», por su forma de resolver la puesta en escena de los diversos conflictos trágicos. Este intento finisecular de adaptar el género a nuestra lengua se produjo tras el desarrollado en medios humanistas durante la primera mitad de siglo.

\footnotetext{
${ }^{3} C f$., para este particular, J.P.W. Crawford (1937) - obra reeditada con adiciones bibliográficas de W.T. McCready, Filadelfia 1967- y M. de los Reyes Peña (1980).
} 
Bien es cierto que tampoco tuvo éxito, pero tuvo, al menos, el mérito de haber preparado el camino para el triunfo de Lope. En las tragedias de este momento se observan básicamente dos tendencias: una de tipo clásico, representada por Bermúdez y la Elisa Dido de Virués, y otra más evolucionada e importante que, partiendo de los clásicos, se aleja de ellos en un deseo de adaptar su arte a los nuevos tiempos: es la dirección que siguen Artieda, Virués en sus otras obras, Cueva, Argensola, Cervantes, Lobo Lasso de la Vega. Mientras que Ruiz Ramón piensa que no triunfaron por falta de una idea clara de lo que debía de ser la nueva tragedia, Hermenegildo cree que las sucesivas tentativas no prosperaron por estar desconectadas de la parte de la población (la masa cristiana vieja) cuyos criterios acabaron imponiéndose, y no tuvo repercusión porque, convertida por sus autores en instrumento de denuncia, atacó de forma muy dura las instituciones y principios.

La tragedia del último tercio de siglo, la que surgía cuando la Comedia Nueva y los corrales estaban haciendo su aparición, pudo llegar a la escena utilizando los tablados de dichos corrales. Estos autores hacen frente en sus obras a un público que hemos identificado como abierto, es decir, al espectador de corrales. ¿De dónde parte este grupo de escritores? Obviamente de las tradiciones griega, latina e italiana. No puede decirse que haya una escuela de tragedia renacentista en España, pero también es cierto que corren, bajo los nombres y las obras atribuidas a dichos autores, dos tendencias claramente marcadas por otros tantos conceptos de poder ${ }^{4}$. Siguiendo en este punto la línea marcada por los estudios de Alfredo Hermenegildo 5 , por una parte, se distinguiría a Gabriel Lobo Lasso de la Vega, junto a los círculos cercanos a la monarquía instalados en la capital del reino, en Madrid, que adopta una actitud admirativa del modo casi divinal seguido por la realeza en el ejercicio del poder. Por otra parte, nacidos en la periferia peninsular -Bermúdez es gallego, Rey de Artieda y Virués son valencianos, Cueva es andaluz, Argensola es aragonés-, los otros trágicos tienen una visión muy pesimista del ejercicio del poder real. Sus obras ponen en tela de juicio la figura de monarcas desprovistos de toda connotación de justicia, de ecuanimidad. Los reyes de ciertas tragedias llegan a estar dotados de rasgos marcados por la locura, por la injusticia, por la crueldad y el espíritu sanguinario y rencoroso $^{6}$. Frente al rey divinizado de Lasso, el monarca demonizado de los trágicos de la periferia.

Hay algo que, desde un punto de vista más técnico, une a todos los escritores mencionados. Es una preocupación común ante las dos variantes de tragedia de la tradición clásica, la aristotélica y la senequiana, muy utilizada esta última por los renacentistas italianos tan presentes en la elaboración de la tragedia española. Algunos de nuestros trágicos parten de modelos grecolatinos y construyen su teatro situándose

\footnotetext{
${ }^{4}$ Según Alfredo Hermenegildo (1973) hay dos tendencias claras que se corresponden con dos visiones del mundo que condicionan las obras de modo diferente, mientras que Rinaldo Froldi (1968) no identifica los conceptos de la vida pública, de la política y el poder, que están subyacentes en las tragedias.

${ }^{5} C f$., concretamente, Hermenegildo (2003), donde ordena y actualiza las ideas aparecidas en sus anteriores trabajos $(1961,1973,1994)$.

${ }^{6} C f$., para la caracterización de estos personajes, Lauer (1987).
} 
en una relación dialéctica con ellos. Toda la aventura teatral del XVI español -y la tragedia de modo más preciso- se lleva a cabo tomando como objetivo la formación de un público. La tragedia renacentista española puede definirse como la acumulación de experiencias tendentes a la creación o al descubrimiento del espectador en el sentido moderno del término. Consecuentemente, la utilización de modelos antiguos y de sus versiones italianas, así como de sus respectivas poéticas, estuvieron condicionadas por la toma de conciencia de la presencia de un público en gestación, de un espectador en potencia, a quien era necesario aprehender y con quien era necesario pactar. Pero no lograron establecer el contacto y el entendimiento definitivos con el nuevo público de corrales, que sí llegaron con la Comedia Nueva.

Estos autores muestran una decidida voluntad de construir tragedia y de llamarla así; algunos hacen incluso una reflexión teórica sobre el ejercicio literario, en general, y sobre su propia producción trágica, en particular ${ }^{7}$. Es el caso de Rey de Artieda, Virués, Argensola y Cueva, como veremos, quienes, en sus planteamientos teóricos, manifiestan una preocupación común por el arte trágico. En su praxis dramática y en su reflexión teórica tomaron como punto de partida el concepto neoaristotélico o el senequiano de tragedia, sobre todo el primero, para alejarse poco a poco de él. Nuestros trágicos fueron suprimiendo paulatinamente las reglas clásicas. El resultado fue su propio fracaso y la consiguiente preparación del triunfo de la Comedia Nueva y del teatro barroco. Los trágicos grecolatinos e italianos fueron, para este grupo de escritores españoles, una referencia constante, pero referencia válida como término a quo, como pretexto para la consecución de un ejercicio de modernidad marcado progresivamente por la negación del modelo inicial o de varios de los elementos constituyentes de dicho modelo, que resultaría abandonado en todo o en parte.

Algunas de las características más significativas de la tragedia de fin de siglo son las siguientes:

- De los dos órdenes de tragedia que identifica Alonso López, «el Pinciano», en 1600 (Carballo Picazo 1953, II, pp.320-321), la patética y la morata, ligada la primera a la tradición aristotélica y la segunda a la senequiana, es el modelo de la morata el que aparece como la marca subyacente en la tragedia finisecular. Para Pinciano, la tragedia «es imitación activa de acción grave, hecha para limpiar los ánimos de perturbaciones por medio de misericordia y miedo» (II, 307). Y ese limpiar los ánimos queda fundamentalmente inscrito en el carácter moralizador de la tragedia de algunos de nuestros dramaturgos. Buscan menos el efecto estético -tragedia patética- que el efecto corrector de las costumbres -tragedia morata-. De ahí la necesidad de conmover los ánimos de los espectadores por medio de acciones brutales, de gestos espectaculares ${ }^{8}$.

\footnotetext{
${ }^{7}$ Para la creación de la tragedia áurea, $c f$. De Armas, García Lorenzo - García Santo-Tomás (2008).

${ }^{8}$ Para la utilización del lenguaje del horror, $c f$. Ly (1983), que ejemplifica precisamente con la producción dramática de Juan de la Cueva. Para el dolor en todas sus variantes, sus causas, efectos y consecuencias, en la tragedia de esta época, $c f$. Hermenegildo (1961, pp.495-515).
} 
- A partir de ahí, y teniendo en cuenta la preocupación por adaptar el marco tradicional de la tragedia a los gustos del espectador contemporáneo, los escritores de fin de siglo adoptan una serie de criterios y fórmulas que alejan de modo notable sus producciones dramáticas de la tradición grecorromana. Así, con arreglo a otra tradición, la del teatro español renacentista, utilizan introitos, prólogos, loas y argumentos al frente de las tragedias. Los actos o jornadas, que eran generalmente cinco, se mantienen en algún autor como Bermúdez o en la Elisa Dido de Virués; pero se reducen a cuatro en Artieda y Cueva, y a tres en Argensola y en las cuatro tragedias viruesinas restantes.

- Los coros, elemento característico de la tradición clásica, desaparecen de las tragedias finiseculares, excepción hecha de las dos Nises de Bermúdez o de la Elisa Dido de Virués. En ciertas obras, es verdad, hay personajes secundarios que, por su intervención hablada más o menos al unísono, recuerdan las formas características de los antiguos coros. Por otra parte, cuando se usa el coro propiamente dicho, actúa según la tradición, como confidente, consejero y consolador del héroe.

- El modelo trágico grecolatino concedía una importancia particular al respeto de las tres unidades dramáticas, aunque dicha importancia estaba más marcada en la práctica escénica renacentista y en la preceptiva literaria de la época que en la historia teatral antigua. Nuestros trágicos, llevados de su afán de modernidad, dejan de lado con frecuencia el respeto de las tres unidades, esto es, se dejan llevar por los aires de renovación, de modernidad, que harían su aparición en la Comedia Nueva y, teniendo como referente la práctica clásica grecorromana y renacentista, le hacen frente y buscan el contacto con un público que prefería otras normas dramáticas.

- Esa búsqueda incansable de un espectador exigente de modernidad, aunque llevó a los trágicos por ciertos caminos de renovación (uso de polimetría, versos cortos -romance, generalmente- mezclados con interminables versos largos), no impedía la aparición de un estilo de gran complejidad, de una retórica ampulosa más cercana, con frecuencia, al discurso literario que al artificio teatral. Y como colofón de ese desajuste entre tradición y modernidad, los trágicos de fin de siglo construyen unos personajes en los que aparece una dramaticidad que resulta postiza; el lenguaje utilizado por algunos personajes (el Príncipe tirano de Cueva, por ejemplo) llega a violentar la esencia dramática de los personajes -figuras elevadas, según la preceptiva aristotélica-. Hay pasajes en los que los autores olvidan bruscamente la categoría dramática del personaje y ponen expresiones desajustadas e inverosímiles en boca de quien debe comportarse según registros más «elevados». El personaje trágico actúa en algunas obras con la liviandad, la grosería o la viveza, si se quiere, del plebeyo.

Todo ello nos lleva a considerar este conjunto de experiencias dramáticas dispersas como el fracaso de un intento, de varios intentos, de elaborar una tragedia renacentista española. Pero si el poco éxito que las obras tuvieron habla de una falta de 
contacto entre el discurso dramático y el que alimentaba la visión popular del mundo, contacto que sí existió al triunfar la Comedia Nueva, no por ello hemos de dejar de lado la existencia de este intento de dramatización que pone en tela de juicio la noción misma de poder político. Si las obras fueron, desde el punto de vista escénico, un fracaso, desde la perspectiva de la sociología literaria aparecen como documentos de extraordinaria significación para explicar un momento histórico: la España de Felipe II.

Buena parte de las obras se inspira en anécdotas extraídas de una historia lejana o inventada (Semíramis, Dido, etc.), otra, en cambio, busca en la historia española los referentes necesarios para su articulación dramática (los siete Infantes de Lara, el fabuloso reino de León en la Casandra de Virués, el saqueo de Roma por las tropas imperiales de Carlos V, etc.). Esta última tendencia, la del teatro inspirado en las raíces historicas de España, es una vía que la Comedia Nueva seguiría más tarde con indudable éxito. Y hemos de añadir que estas tragedias, inspiradas en la tradición histórica o histórico-fabulosa, no hacen más que emplear los referentes del pasado para llevar a las tablas unas preocupaciones «actuales». No se trata de simples reconstrucciones arqueológicas de un pasado fenecido, sino la expresión, a través de un pretexto histórico, de los problemas que planteaba la convivencia colectiva en la España del siglo XVI.

La catarsis aristotélica, el desahogo emocional derivado de la excitación de la misericordia y el miedo con el que se crea un efecto estético, no conlleva influencia moral alguna. Por eso fue modificada por los renacentistas, tan preocupados por el fin docente del ejercicio literario. Alejados ya de la idílica y abstracta contemplación de una armonía cósmica, típica del Renacimiento, se entra en una época de contradicciones, en un período conflictivo (Froldi 1999, pp.20-21). El horror, ciertamente, es un recurso efectista teatral, pero también una profundización ideológica: no se trata ya del razonamiento sosegado humanista y universal, sino de un realismo pesimista y agresivo que echa en cara el horror de la realidad que se vive.

\section{JUAN DE LA CUEVA (SEVILLA, 1543 - GRANADA, 1612)}

\subsection{APROXIMACIÓN A LA FIGURA Y LA OBRA. LA CULTURA CLÁSICA EN SU FORMACIÓN Y LA TRADICIÓN CLÁSICA EN SU OBRA}

Poco a poco, la imagen estereotipada de Juan de la Cueva como dramaturgo prelopista va cediendo a otra muy diferente y mucho más amplia y variada: la de poeta que ensayó casi todos los géneros de poesía que estuvieron de moda en su tiempo: romancerista prolífico, compositor de «coplones, no tersos, pero tercos para el pueblo», en palabras de José Cebrián García (1986, p.XI), autor de un vasto cancionero amatorio, satirista inmisericorde y mordaz, poeta épico, epistológrafo, traductor y preceptista 9 .

\footnotetext{
${ }^{9}$ Para la biografía de Juan de la Cueva siguen siendo de obligada referencia las páginas del editor de su teatro, Francisco A. de Icaza (1917, pp.V-LVI; 1973, pp.I-XXXIX). Mucho más reciente es el capítulo «Para la biografía de Juan de la Cueva» que le dedica J. Cebrián García (1991, pp.15-64), en su volumen de Estudios.
} 
Importante precursor de la Comedia Nueva, nació en el seno de una familia ilustre ${ }^{10}$. Creció cerca de figuras como Juan de Mal Lara o Fernando de Herrera y dio tempranas muestras de su gusto por la poesía y el teatro participando en academias literarias. Escritor polifacético, cultivó la lírica en su juventud -primero en línea petrarquista, luego dentro de un cauce más tradicional-. Entre 1574 y 1577 estuvo en México, donde publicó algunos poemas, y a su vuelta a Sevilla empezó a representar sus obras teatrales, en un conjunto formado por diez comedias y cuatro tragedias que fueron impresas en Sevilla en $1588^{11}$. Escribió también dos fábulas mitológicas breves en octavas reales: el Llanto de Venus en la muerte de Adonis (1582) y Los amores de Marte y Venus, fechada en 1604, pero compuesta, acaso, mucho antes. En ellas se aprecia claramente el débito del sevillano con Ovidio pero también con Homero y Virgilio, en donde demuestra una encomiable capacidad para ordenar los materiales, agrupar las diversas influencias, reorganizarlas y aplicarles justamente el aparato retórico y los recursos estilísticos propios del género. Y ha de sumarse un poema épico-burlesco en verso suelto y octavas que narra los avatares de una cruenta batalla entre gatos y perros a orillas del río Guadalquivir: La Muracinda (1604?). En los últimos años de su vida, ya comenzado el nuevo siglo, publicó el poema épico Conquista de la Bética, sobre la conquista de su ciudad natal por Fernando III el Santo, y compuso una interesante obra de preceptiva sobre el arte dramático, el Ejemplar poético (1606), precisamente cuando ya llevaba bastante tiempo alejado de la escena. Después de 1610 aparece viviendo algún tiempo en Cuenca y, finalmente, en Granada, donde murió.

La educación de Juan de la Cueva fue de tipo humanista, formada en la Universidad de Sevilla, entonces dominada por la personalidad de Juan de Mal Lara. De su formación clásica tenemos suficientes testimonios, tanto en su teatro, llamemos, «senequista» como, sobre todo, en el resto de su producción poética, si bien se trata de un elemento accesorio y retórico. Su teatro no pretende ser una copia o reconstrucción arqueológica de lo antiguo; al contrario, evidencia una precisa voluntad de realizarse como cosa nueva y distinta. En efecto, se rebela contra la tradición clásica y erudita, alejándose del rigorismo técnico del clasicismo.

Poco se sabe de su primera juventud, aunque debió de comenzar pronto sus estudios de Humanidades, quizá bajo la tutela de Juan de Mal Lara. Son éstos los años en que Cueva se aplica al estudio de la poesía latina, interpreta a los clásicos y

\footnotetext{
Una interesante aproximación titulada «Resumen bio-bibliográfico», entreverada con textos de Juan de la Cueva, nos ofrece el propio Cebrián García (1984, pp.11-32) en su edición de las fábulas mitológicas y la épica burlesca. Por otro lado, Rinaldo Froldi (1999, pp.15-17) nos ofrece una visión de conjunto sobre los estudios dedicados al sevillano. Cf. también Rodríguez Marín (1923, pp.513-516), Hermenegildo (1961, pp.284-291; 1994, pp.250-255), Reyes Cano (1980, pp.57-88) y Glenn (1973).

${ }^{10}$ Gran cantidad de detalles aporta el propio autor sobre su familia en el poema épico de asunto genealógico Historia y sucesión de la Cueva (1604).

${ }^{11}$ Debió de componer otras piezas dramáticas, ya que hay un poder firmado en 1595 con el que Cueva autoriza a solicitar licencia para imprimir y vender una Segunda parte de las comedias y tragedias, de la que no hay rastro alguno.
} 
adquiere una sólida formación petrarquista. $\mathrm{Y}$ al tiempo que adquiría conocimientos debió de surgir su vocación literaria, cuyos primeros frutos consistieron en ejercicios de traducción y en poemas de corte amatorio. Con carácter general puede decirse que como fuentes de su teatro, en las obras que no son de pura inventiva, hay que contar, en primer lugar, con las reminiscencias clásicas. Que Cueva conoció los originales latinos parece indudable. Y, por no hablar solo de temas, podemos también mencionar el lenguaje altisonante, lleno de pompa clasicista. Puede afirmarse que el arte de Juan de la Cueva, en parte de su producción, consiste en la fusión de lo humanista y lo tradicional (Wardropper 1980); la Edad Media se infiltra en algunos dramas de concepción renacentista; la poesía y los sentimientos populares coexisten con el arte erudito.

Tanto Cueva como los otros trágicos de este período se acercaron a la Antigüedad para comprenderla, pero no para imitarla. No hay más imitación que la de la técnica teatral. No se someten a las leyes de Aristóteles, a pesar de las reiteradas manifestaciones que hicieron en pro de su conveniencia. Se apartan, incluso, de toda traducción. A la tragedia griega se prefiere la latina y Séneca se yergue como modelo a través de su moral estoica cristianizada, de su sentenciosidad retórica, de su efectismo que se manifiesta sobre todo a través del elemento agresivo, violentamente provocativo del horror.

La influencia del teatro de Séneca en esta época apareció más tarde que en la literatura italiana y francesa, y esencialmente se limita al tiempo que va de 1575 hasta, aproximadamente, 1590 , finalizando en el momento en que, gracias a la intervención de Lope de Vega, empezó a imponerse en España un teatro independiente ${ }^{12}$. Parece que fue Giambattista Giraldi Cinthio (1504-1573) el que primero recurre al modelo de Séneca y aboga decididamente por su imitación desde el punto de vista teórico en su Discorso delle commedie e delle tragedie (1543). Hay que tener en cuenta que, tal vez, el hecho de que no se publicaran en España traducciones de las tragedias de Séneca en todo el siglo XVI pudo haber tenido un efecto «retardador». Otro dato a tener en cuenta en el caso de nuestro autor es que Juan de Mal Lara, que tanta influencia ejerció sobre él, pudo haber seguido ya el modelo de Séneca antes del último cuarto del siglo XVI. El hecho es que las primeras tragedias españolas escritas de acuerdo con los cánones clásicos y a imitación de las de Séneca son Nise lastimosa y Nise laureada de Jerónimo Bermúdez, publicadas en Madrid en 1577 con el título de Primeras tragedias españolas. Poco después se representarán en Sevilla, entre 1579 y 1581 , las de Juan de la Cueva, autor en el que pronto se deja sentir el influjo de Séneca (Morby 1937). Las características típicas de la técnica senequiana, que pueden apreciarse, entre otras, en la Tragedia del Príncipe tirano, son las siguientes: retórica efectista, frecuente uso de monólogos ya al principio de la pieza, el propio contenido de los monólogos, que va desde las efusiones filosóficas a las excursiones líricas, la trascendencia de lo sobrenatural y la magia, las pasiones de-

\footnotetext{
12 Para la importancia de las tragedias de Séneca en el teatro español del siglo XVI, $c f$. K.A. Blüher (1983, pp.318-330). Puede consultarse también A. Hermenegildo (1961, pp.533-544).
} 
senfrenadas, venganzas, horrores, crímenes y cruel derramamiento de sangre. Pero hay que señalar que, a pesar de ello, no se han encontrado reminiscencias verbales de las obras del cordobés ${ }^{13}$.

Antes de la aparición de Lope, pues, los dramaturgos españoles rindieron homenaje por corto tiempo a las imitaciones de Séneca que reinaban entonces en Europa. Pero hay que reconocer que el impulso de estas imitaciones nació menos de un uso directo de las tragedias de Séneca que de modelos italianos.

\subsection{LA PRODUCCIÓN DRAMÁTICA Y LA REFLEXIÓN SOBRE EL ARTE DRAMÁTICO}

\subsubsection{El Ejemplar poético}

Junto con Virués y Cervantes, Juan de la Cueva es el autor más significativo del grupo que cierra el siglo XVI, si bien ello no le ha liberado de ser objeto de consideraciones contradictorias. Este sevillano, que hacía gala de serlo, en cuyos corrales de Don Juan, Doña Elvira y las Atarazanas vio representar sus obras entre los años 1579 y 1581, nos legó una, cuando menos, curiosa producción dramática. Relacionado con ella, se encuentra el Ejemplar poético (1606), nunca publicado en vida de su autor, que supone una reflexión sobre la poética, en general, y sobre el arte dramático, en particular. Había ya dejado de escribir teatro cuando se enfrentó con el problema teórico y, curiosamente, no trató de defender sus antiguas prácticas de creación. Los problemas planteados reflejan un concepto del arte escénico más cercano a la Comedia Nueva que a las realizaciones dramáticas del propio autor. El sevillano no pudo seguir a Lope de Vega, pero tuvo que contar con él al reflexionar sobre la práctica teatral. Esta obra, que no cuenta con una organización ni estructura claras, recoge casi todos los motivos de la cultura de su tiempo y expone los problemas críticos, si no con originalidad, al menos con bastante personalidad. Es una imitación de Horacio pero la doctrina se funda en temas más modernos. Lo cierto es que la técnica y la esencia dramática del teatro de Cueva debe sacarse, antes que del Ejemplar, más de un cuarto de siglo posterior a la redacción de sus obras, de sus propias tragedias y comedias. El teatro lopesco ya había triunfado y volver la vista atrás carecía de sentido. Así, defiende el cambio de las leyes dramáticas ateniéndose a la necesidad de ajustar las obras a las exigencias de su público. Si el teatro español empezó siguiendo la vía de los modelos clásicos y de la tradición humanística italiana, Cueva y los de su generación vieron la urgencia de aplicar modelos nuevos y rompió en buena parte los moldes preestablecidos. Por eso su teatro es un ejercicio

${ }^{13}$ Cf. E. del Río (1992, 392-425) para el influjo de Séneca en el teatro de Juan de la Cueva, que no se manifiesta ni en los temas de las obras, ni en el mayor o menor seguimiento de las reglas dramáticas, a pesar de que conocía los argumentos de las obras de Séneca, como puede comprobarse en el «Romance a la Musa Melpómene», recogido en el primer Coro febeo de romances históricos. 
de transición, visto, evidentemente, desde nuestra perspectiva (Cebrián García 1991, pp.125-138).

Más allá de la imitación de Horacio, el texto está plagado de nombres mitológicos (Orfeo, Amor, Satúrneo Júpiter, Baco, Venus, Marte, Caos, la Parca, Minerva, Jove, Prometeo, Pan, Fauno, Creonte, y, por supuesto, Febo Apolo y las Musas), de autores griegos y latinos (Homero, Virgilio, Alcmán, Empédocles, Eráclito (sic), Demócrito, Anacreón, Esquilo, Sófocles, Servio, Donato, Horacio, Menandro, Píndaro, Museo, Alceo, Ennio, Nevio, Accio, Plauto, Séneca), de personajes de la Antigüedad, lugares geográficos (la cumbre del Helicona, el Pireo, Castalia, el Lacio, el Bóreas, el Céfiro, Híspalis, Arcadia, Augusto, ...), etc. La obra, dividida en tres epístolas, comienza con estos versos (vv. I, 1-18) ${ }^{14}$ :

Sobre el ingenio y arte disputaron

Palas y el fiero hijo de la Muerte a quien del cielo por odioso echaron.

La sabia diosa su razón convierte en decir que el ingenio sin el arte es ingenio sin arte cuando acierte.

De estas dos causas seguiré la parte por do el ingenio inspira, el arte adiestra sin que de su propósito me aparte.

Si admite la deidad sagrada vuestra, Fébeas culturas del Helicón divino, comunicarse a la bajeza nuestra.

$\mathrm{Y}$ adiestrándome vos por el camino

de la vulgar rudeza desviado, a su brutez profana siempre indino,

llegaré al punto en que veréis cantada

lo que el Arte al ingenio perfecciona, y de quien es, si ha de acertar, guiado.

Es el propio autor el que reconoce los antecedentes (vv. I, 142-147):

Y si tú que lo ignoras, no te allegas a seguir esto, y porque a ti te admira lo menosprecias, y su defecto niegas, lo propio dice el sabio de Stagira a quien Horacio imita doctamente en dulce, numerosa y alta lira.

En su recorrido por los distintos géneros y formas literarias van apareciendo los principales autores, si bien no es menos cierto que hay algunas ausencias más que

\footnotetext{
${ }^{14}$ Citamos por la edición de F.A. de Icaza (1973, pp.117-169). La obra está dedicada a D. Fernando Enríquez de Ribera, Duque de Alcalá, Marqués de Tarifa: «Vos a quien Febo Apolo da su asiento / y las Musas celebran en su canto / y el vuestro escuchan con discurso atento» (vv.25-27).
} 
significativas. Veamos, a modo de ejemplo, un par de fragmentos de la primera epístola (vv. I, 244-249 y I, 505-513):

Nicandro en su Triaca celebrada

dicen que no es poeta, y que Lucano

no lo fue en su Farsalia laureada.

Históricos los llama Quintiliano

porque tanto a la Historia se llegaron.

Poetas a Platón y Luciano.

A Séneca dejó el lloroso oficio

de la tragedia, a Plauto y a Cecilio

de la vulgar comedia el ejercicio.

Cantar las armas remitió a Virgilio,

el de Ascra de Dioses y labores,

a quien dio Apolo celestial auxilio.

La lírica dulzura y los amores

a Horacio y a Tibulo, y al fogoso

Juvenal murmurar vicios y honores.

La Epístola II está dedicada principalmente a los autores españoles, aunque el reflejo de los clásicos siempre está presente, como en estos versos en que los grecolatinos se convierten en modelo (vv. II, 40-42):

De nuestro español verso el elegante

método, el armonía y la dulzura

a la griega y latina semejante.

Del mismo modo que, refiriéndose a los personajes, pone también como modelo que identifica «tipos» a los clásicos (vv. II, 328-330):

Sin que trates de Alcestes ni de Aquiles

en el sublime estilo, ni lo abatas

a Sosia, o Davo, en condición serviles.

En la Epístola III, más llena si cabe de referencias clásicas de todo tipo, hace unas interesantes reflexiones sobre el uso de cultismos y latinismos, a los que califica de «vocablos ascondidos» (vv. III, 61-69):

Sclopetum llamaban a la escopeta, estapeda decían al estribo, famélica curante a la dieta.

Al maldiciente le decían cancivo, a la casa común de la vil gente público alojamiento del festivo. 
Carnes privium, llamaban comúnmente

a las carnestolendas, y así usaban

de aquesta afectación impertinente.

Y encontramos una exaltación del Betis, el río de su tierra, Sevilla, de la misma manera que en el Laurel de Apolo de Lope de Vega hallamos la entronización del Manzanares (vv. III, 448-452):

O el mantuano Dauro que el Parnaso

con abundante vena de oro riega,

y al Tebro y Arno les impide el paso.

Y tú, ¡oh, fecundo Betis!, cuya vega

enriqueció la sacra musa albana

que a los confines celestiales riega.

Finalicemos estas breves referencias a la preceptiva de Juan de la Cueva con alguna de sus reflexiones a propósito del teatro, para que cuando veamos los textos de sus obras caigamos en la aparente contradicción ya mencionada (vV. III, 703726):

Aplica al verso trágico la alteza

épica, y dale lírica dulzura

con affectos suaves, sin dureza.

Con epitetos adornar procura

tus versos, que al poeta hermosean, $y$ al orador ofenden la escritura.

En la tragedia alguna vez afean

los sucesos contados de otra suerte

dando ocasión que la verdad no crean.

$\mathrm{Y}$ si en este preceto no se advierte

la Historia en que se funda la tragedia

se ofusca y de lo cierto se divierte.

De fábula procede la comedia

y en ella es invención licenciosa

cual vemos en Naharro y en Heredia.

El cómico no puede usar de cosa

de que el trágico usó, ni (a) un solo un nombre

poner, y ésta fué ley la más forzosa.

Si quieres que se estime, y que se nombre

tu musa, y que a las musas dinamente

te hagan de mortal, inmortal hombre;

hállete el vulgo siempre diferente

en lenguaje, pues hablan los poetas

en otra que la ruda gente. 


\subsubsection{Las comedias y tragedias}

Sus catorce dramas ${ }^{15}$, concebidos para ser representados en los corrales sevillanos, fueron publicados en Sevilla en 1588, en el tomo Primera parte de comedias de Juan de la Cueva. Llamó, de manera no muy justificada, comedias y tragedias a sus obras. Entre las primeras están: La muerte del rey don Sancho y reto de Zamora; El saco de Roma; La libertad de Roma por Mucio Cévola; El degollado; La libertad de España, por Bernardo del Carpio; El infamador; El viejo enamorado; La constancia de Arcelina; El tutor y la Comedia del Príncipe tirano. Las tragedias son: Los siete Infantes de Lara; Áyax Telamón; La muerte de Virginia y Apio Claudio y la Tragedia del Príncipe tirano.

Dejando de lado la caprichosa e imprecisa división en comedias y tragedias se puede recurrir, más bien, para clasificarlas a los referentes empleados por el autor. Las piezas basadas en las historias del rey don Sancho, del saco de Roma, de los Infantes de Lara o de Bernardo del Carpio, son obras atadas al pasado nacional, lejano o cercano. El uso de la historia española es un rasgo muy significativo en la aventura dramática de Cueva. Añadamos que tal uso de la historia oculta una dramatización de la realidad «contemporánea» que no debe dejarse de lado. Leyendo así el teatro de Cueva, resulta significativo el uso dramático de romances tradicionales, como ocurre en El rey don Sancho, lo que supone un paso adelante en la elaboración del contacto con el nuevo público de los corrales. En dicha obra lo más llamativo es la inversión de los papeles del rey, don Sancho, y del traidor, Vellido Dolfos. Don Sancho es aquí el injusto, el tirano, el malvado; Dolfos es el vengador y el liberador. Anthony Watson (1971) ha visto en los gestos del rey ambicioso y agresor de la soberanía del país vecino, León, un ejemplo bien negativo de lo que la España de Felipe II no debería hacer con la nación portuguesa. Parecido problema plantea El saco de Roma, obra construida en torno al saqueo llevado a cabo en 1527 por las tropas imperiales de Carlos V.

De las tres piezas dedicadas a la historia mítica clásica, las que tratan de Virginia y Apio Claudio, de Áyax Telamón y de la libertad de Roma, es la primera, como veremos con más detenimiento, la que se acerca más a los cánones tradicionales.

Dentro del grupo de obras de trama novelesca (Arcelina, El degollado, El tutor, ...), siempre se ha destacado El infamador, representada en el patio de Doña Elvira en 1581. La razón de su fama hay que buscarla en un malentendido crítico. El héroe, Leucino, no es, ni mucho menos, la primera textualización del mito teatral de Don Juan. El hecho de que Leucino acose a Eliodora no es motivo suficiente para transformar al personaje en una encarnación del Don Juan Tenorio. Más importancia tiene desde un punto de vista socio-político, ya que, junto con las dos piezas gemelas,

\footnotetext{
15 Los fragmentos se citan por la edición de F.A. de Icaza (1917), salvo Los siete Infantes de Lara y El infamador, por la de F.A. de Icaza (1973). Las referencias a la edición de 1917 se hacen siempre al número de página, con indicación previa del volumen, ya que los textos de las tragedias y comedias no presentan numeración en los versos. Sí llevan indicación del número de verso, precedido en este caso de la jornada en números romanos, las obras citadas por la edición de 1973.
} 
la comedia y la tragedia de El Príncipe tirano, forma una trilogía en que aparecen señales probables de la opinión pública en torno al problema de la sucesión al trono de Portugal, vacante tras la trágica muerte del rey don Sebastián en Alcazarquivir.

En el Laurel de Apolo de Lope, tan pródigo en alabanzas, no se cita en parte alguna el nombre de nuestro trágico. Esta omisión podríase considerar muy grave si, realmente, Cueva fuera el verdadero predecesor de Lope. Por su parte, Cervantes, en el Canto de Caliope, cita a un tal Juan de las Cuevas, pero de forma muy imprecisa. Y el Viaje entretenido de Agustín de Rojas, al hablar de la introducción de reyes en el teatro, cita dos comedias de Cueva donde se trata del padre tirano y añade que nuestro autor fue el primero en tratar el tema. Pero al hacer Rojas un recorrido por todos los autores, cita muchos, incluso de segundo y tercer orden. Con mayor o menor unanimidad los críticos le califican de improvisador e innovador. La primera calificación explicaría todas las deficiencias y errores de su teatro; la segunda, el puesto destacado, como inmediato precursor de Lope de Vega y como iniciador de nuevos caminos dramáticos.

Cueva alaba las obras escritas en Sevilla al estilo clasicista, pero sostiene que la reforma del drama, a la que él contribuyó notablemente, era necesaria. Defiende el cambio de las leyes dramáticas hecho por los españoles, en el sentido de que no fue provocado por la ignorancia ibérica, sino por la necesidad que sentían de ajustar tales preceptos a las exigencias de la época. En sus obras están, por lo menos en germen, todas las características técnicas fundamentales del teatro español. Tomó del clasicismo, aparte de una formación más o menos sólida, la naturaleza de las situaciones y episodios. Es en este último punto donde la presencia senequiana es evidente. La situación de nuestro dramaturgo en el teatro español quedó determinada con las palabras de Ángel Valbuena Prat (1956, p.50):

Viene a ser un enlace entre las tendencias clásicas de la tragedia y el mundo poliforme de los argumentos novelescos del drama italiano (...) Con todo el peso arqueológico de su tragedia, bastan los nombres y los temas para comprender que nos encontramos en el caso más interesante de prelopista, si se exceptúa a Cervantes.

Empezó Juan de la Cueva por desdeñar la sencillez del teatro de Lope de Rueda y quiso imprimirle un violento impulso capaz de conducirle por nuevos derroteros. Sacó el teatro del ambiente familiar para llevarlo por cauces sociales y políticos, pero le faltó ser un gran genio para dar cima a su obra. Su primera gran aportación es haber introducido en la escena española personajes históricos muy representativos, unos de la antigüedad clásica (Áyax, Virginia) y otros de nuestra historia nacional y el romancero (Mudarra, el rey Don Sancho muerto ante los muros de Zamora, etc.). Inicia asimismo la dramatización de grandes temas contemporáneos. También lo sobrenatural fue muy utilizado por él como resorte dramático ${ }^{16}$; los espíritus son invocados para

\footnotetext{
16 Para la presencia de lo sobrenatural, el tránsito del paganismo al cristianismo, el fatum y la providencia en las tragedias, la rebelión contra el destino y la insolencia con los dioses, junto al uso de lo fantástico, divinidades, espíritus y figuras alegóricas, $c f$. A. Hermenegildo (1961, pp.479-494).
} 
descubrir los asesinatos, los sueños juegan un papel muy importante, los dioses intervienen en los asuntos de los hombres, el deus ex machina protege a sus favoritos, etc. Se ha insistido mucho en la sobreabundancia perjudicial de figuras mitológicas en el teatro de Cueva, pero si ello es un defecto no fue propio de él porque es característica común de muchos autores. Sí hay que afirmar que esa facilidad de invención le llevó a construir los planes de sus obras de manera desordenada e irregular. Sus acciones no se desenvuelven lógicamente; en general no son más que una continuación de sucesos y de situaciones incoherentes y a veces inverosímiles. De esta mancha se salvan, en parte, las cuatro tragedias, que están algo más sujetas por la fuerza que imprime un tema antiguo, cerrado, o un romance castellano. No obstante, también aquí hay situaciones precipitadas por la imaginación. Destaca, en cambio, Alfredo Hermenegildo (1973, pp.283-285) que, si bien la crítica ha sido unánime al condenar la inverosimilitud de los caracteres de Cueva, es precisamente en las anormalidades de los personajes donde tenemos que descubrir la intención del autor: sus personajes esconden algo más que un puro error de dramaturgo que no supo respetar las leyes de la verosimilitud. En primer lugar no le interesó demasiado el seguimiento de las leyes y, además, en el hecho de no obedecerlas habría que buscar la razón justificativa de su teatro. Cueva se aleja en la elaboración de algunos de sus personajes de todos los preceptos, incluidos los de la moral más elemental. Su indiferencia ante las criminales intenciones y hazañas de algunos personajes hace pensar que sentía cierta simpatía por ellos. O bien que no son sino la hipertrofia burlesca de una situación social con la que era necesario acabar. El teatro sería así un espejo de buenas costumbres contando con la necesaria inversión de valores a la hora de descodificar el mensaje. Tiende a usar un lenguaje pomposo y altisonante, marcado por la falta de adecuación al personaje que lo utiliza, y lo mismo aparece en boca de reyes que de villanos, de verdugos que de idílicos pastores. Rompe así el decoro y la verosimilitud del teatro tradicional y de algún modo se inscribe en una práctica escénica que mezcla personajes y lenguajes altos y bajos, es decir, la práctica seguida por la Comedia Nueva. En cuanto a la estructura y división de las piezas, se apartó del clasicismo. Prescindió de las unidades de tiempo y lugar, sin ver inconveniente, por ejemplo, en que Mudarra vengase a sus hermanos en el último acto cuando en el primero permanecía aún en el vientre materno. Tampoco le preocupó la unidad de acción e, incluso, se podrían suprimir muchas intrigas secundarias, escenas y personajes, sin que se resintiera el tema central.

Entonces, es preciso hacerse dos preguntas, como señala acertadamente Alfredo Hermenegildo (1994, p.254): ¿Cómo es posible que un autor tan «mediocre» viera representadas sus obras de modo tan intenso entre los años 1579 y 1581 y luego desapareciera de los tablados públicos? Y, ¿no habrá que poner en la balanza del juicio crítico la propia temática del teatro de Cueva y sus connotaciones políticas? Concluye el estudioso del sevillano que su teatro es una reflexión sobre el poder en general y una dramatización de ciertos aspectos de la vida política española. Los problemas relativos a la sucesión al trono de Portugal y las aspiraciones del rey Felipe II a ocuparlo después de la muerte del rey don Sebastián en Alcazarquivir parecen estar presentes 
en la motivación primera de una parte del teatro de Juan de la Cueva (Watson 1971). ¿Dejaron, pues, de representarse sus obras por no ser percibidas como leales a la política oficial del trono? El problema queda planteado.

\subsubsection{Lo clásico como tema y como ornato}

Obviamente no ha lugar ocuparse de las catorce tragedias y comedias de Juan de la Cueva por lo que hemos procedido a hacer una selección, seguro que arbitraria como todas las selecciones, en la que nos acercaremos a las cuatro tragedias, a la comedia de tema clásico, la del Príncipe tirano, por su relación con la tragedia del mismo título y, por último, a El infamador, de tema no clásico pero en realidad una farsa mitológica.

En Los siete infantes de Lara es más importante, tal vez, considerar el intento renovador de la temática y fuentes del teatro español que el carácter trágico, y truculento, de su contenido, pues, desde esta última perspectiva, la obra tiene la flaqueza de que la tragedia de los siete Infantes queda mitigada con la muerte final de los traidores. La obra encaja en ese nuevo género que ha sustituido el fatum por la venganza. El autor considera también trágico no solo el desenlace de los traidores, sino la vida del vengador, obligado por el peso de las consideraciones sociales o familiares a llevar tan atroz acción a cabo. Cueva prescinde de las unidades preconizadas por la preceptiva clásica y sitúa la acción en Córdoba, Barbadillo y Salas, a lo largo de unos veinte años, y el tema principal no aparece sino en la parte final de la obra, pudiéndose suprimir, incluso, el acto tercero. Es importante señalar que las figuras recuperadas por el autor no siguen el modelo que les había otorgado la tradición, sino que aparecen revestidas con sentimientos e ideas del siglo XVI, salvándose, si se nos permite así decirlo, el personaje de Mudarra, concebido con exagerado resentimiento y odio cuyo único destino es la venganza, y que se presenta como un fanfarrón insoportable cuando, en su locura final, reta a Ruy Velázquez concediéndole toda clase de ventajas.

Por lo que se refiere a tradición clásica, hay que señalar que no hay ningún personaje clásico, ni ninguna alegoría, si bien las reminiscencias y referencias clásicas se deslizan, de forma casi inevitable, como cuando el capitán moro Viara, al inicio de la segunda jornada (vv. 2.4-6), dice:

\section{VIARA: Nací de padres pobres; fuí criado en una honesta medianía, sujeto a la disposición del veloz Hado.}

Aunque llaman más la atención las intervenciones de la mora Haja (vv. III, 53-58) y del rey Almanzor (III, 226-227; 230-231; 240-243):

HajA: Ministros del Averno, a quien la luz hermosa del claro y rutilante Febo ofende, 
salid del llanto eterno

y cárcel trabajosa

a remediar el mal que nos enciende.

AlmANZOR: El nombre de Almanzor en voz sonora

se canta desde Tetis al Aurora.

...

del nombre mío treme y se retira, y el ciego amor de Marte no le instiga.

Seguro estoy; Fortuna rigurosa

favorable me ha sido, y en su despecho

ha vuelto en piedad y amor conmigo,

pues vencí tan magnánimo enemigo.

El estilo de la tragedia es irregular, mezclando fragmentos de gran altura con otros realmente mediocres. Veamos como ejemplo la enrevesada metáfora que la hermana de Almanzor, Zayda, utiliza en la última jornada para indicar el paso del tiempo (vv. IV, 5-8), cómo no, adornada con personajes de la mitología clásica:

\section{ZAYDA: Ceres con rica y fértil opulencia \\ ha diez y siete veces el granero \\ del labrador solícito colmado, \\ y Baco se ha otras tanta coronado.}

Asegura Icaza (1973, p.XLII) de las reminiscencias clásicas, sobre todo de Virgilio y Ovidio, que:

Las hay hasta en las comedias de asunto español. En Los siete Infantes de Lara (...) comienza la jornada tercera con una escena entre Çayda y Haxa, imitada de la Pharmaceutria, de Virgilio -según notó ya Menénedez Pidal-. Las evocaciones y sortilegios de esa y otras comedias no son sino paráfrasis fragmentarias de las mismas fuentes. En Ovidio halló alguna trama escénica completa; la de Ayax Telamón (...). Cueva diluye el tema en cuatro larguísimas jornadas; pero alguna vez traduce, siquiera sea libremente. Que Cueva conoció los originales latinos es indudable.

La tragedia de Áyax Telamón, junto con La muerte de Virginia y la comedia de La libertad de Roma por Mucio Cévola, son las tres de tema clásico. Trata de la muerte de Áyax junto a las armas de Aquiles, después de la disputa con Ulises sobre quién tenía que ser el dueño de tales armas. En las primeras escenas Cueva tendría que haber imitado una buena parte del libro segundo de la Eneida, pero siguió las Metamorfosis de Ovidio, concretamente el libro XIII (vv.1-399), en los discursos de Áyax y Ulises, si bien los reduce.

Hay que señalar que Cueva, abandonando la rapidez con que Ovidio plantea el tema, malgasta una jornada en diálogos vacíos entre Agamenón y Menelao. Como señala A. Hermenegildo (1973, p.295), podría pensarse en alguna relación de Cueva 
con Sófocles, pero sus dos tragedias no tienen en común más que el nombre del héroe. El editor de las tragedias, Icaza (1973, p.XLII), asegura, tratando de fundamentar en lo popular toda la producción de Cueva, que debió de conocer los originales latinos:

Aunque es de creer que no habría abordado este último asunto si la Crónica Troyana, tan reimpresa a partir de las ediciones incunables, no lo hubiera hecho popular. Otro tanto podría decirse de La muerte de Virginia y de La libertad de Roma por Mucio Cévola. Tito Livio dio hecho a Juan de la Cueva el asunto y la trama primera; pero los episodios de la historia romana, insertos en las crónicas, no le serían de seguro desconocidos ni a él ni a buena parte del público, aunque dudo mucho hubieran llegado a la gran masa de su auditorio popular, como no fuese en romances sueltos del género de los que reunió el propio Cueva en el Coro Febeo, donde aparecen algunos sobre esos mismos sucesos historiales. Ni la contienda de Ayax tiene precedente alguno en el teatro español (...) ni tiene tampoco antecedente teatral conocido su Muerte de Virginia.

En cuanto a la estructura dramática hay que destacar que la jornada primera no tiene ningún sentido, pues no hace más que presentar la parte vencida de la guerra, sector que no actúa en el hecho central de la obra. Así también, la presentación de los caracteres de Eneas, Anquises, Acates, Elena, Andrómaca y Canopo está fuera de lugar. Algo parecido podría decirse de la segunda jornada, que se pasa en una absurda discusión que obliga a Agamenón a dejar el arreglo para el día siguiente, de modo que solo las dos últimas jornadas se dedican a la acción principal. No respeta ninguna de las tres unidades: la acción se desarrolla en Troya, en el Monte Ida y en el campamento griego, no hay unidad de acción por lo que hemos dicho y además se incluyen elementos inverosímiles como la conversión de Áyax en flor.

Los dos protagonistas, Áyax y Ulises, pierden la debida altura trágica cuando se enzarzan en peleas ofensivas, más propias de pícaros (Icaza 1917, pp.I, 314-315):

ULISES: No es huir de las peleas.

ÁyAX: Cobarde, ¿quién á huydo?

ULISES: Baladron, y ¿quién te teme?

ÁYAX: ¿Quién? El que de verme treme, que eres tú, vil abatido.

El autor tiende a rebajar la altura de los héroes, a desmitificar la fábula clásica, en beneficio de una agresividad verbal muy poco verosímil en un personaje de dimensiones épicas. La desmesura en la presunción aparece más marcada en el personaje de Áyax, insoportablemente arrogante y altanero, más fanfarrón que valiente, que incluso se permite enjuiciar la figura de Ulises, a quien siempre considera inferior a él. No es, pues, un disparate decir que Cueva se equivocó en la caracterización de los héroes de esta tragedia. Sirvan de ejemplo estas palabras de Áyax (Icaza 1917, pp.I, 308-309):

AYAX: No os quiero recitar lo más qu'é hecho, pues lo sabeys mejor que yo os lo digo, 
y no está en que os lo diga mi derecho, pues desto es todo el mundo buen testigo;

$\cdots$

A Vlisses dalde afeytes, dalde juegos, dalde trayciones, ques lo quél á usado; no esteys en este parecer ya ciegos; que claro está lo qu'es por mí alegado: vosotros los sabeys, y assi, concluyo ser mias las armas, y el hablar ser suyo.

De lo dicho ya puede deducirse como incomprensible la intervención de la Fama al cerrar la obra con una gran alabanza para ensalzar en Áyax, ya muerto, unas virtudes que no han aparecido a lo largo de la obra. Ulises, por el contrario, es presentado por Cueva como más apagado en energía, si bien más cercano a la legendaria «realidad».

En cuanto al estilo y el lenguaje hay que decir que el autor utiliza en alguna ocasión el aire popular de los bandos o pregones trasladado al mundo de los griegos, como por ejemplo en éste en redondilla que lee el Atambor (Icaza 1917, p.I, 289):

ATAMBOR: Siendo Troya destruyda, manda el fuerte Agamenon a su greciano esquadron que se apreste a la partida. Porqu'en mostrandose el viento bonancible, el mar tratable, siendo el Cielo favorable, no se detendra momento.

Como excepción al tono amoral con que, como hemos indicado anteriormente, nuestro autor se enfrenta a las mayores atrocidades y aberraciones sin plantearse el problema religioso, podemos citar, en la segunda jornada, la ofrenda de Agamenón a los dioses (Icaza 1917, pp.I, 295-296):

AgAmENón: ¡O Iupiter soberano,

tu alto favor acuda, dando tu siderea ayuda al exercito greciano.

Recibe este sacrificio humilde, y tu esposa Iuno lo acepte, y el gran Neptuno y Eolo nos sea propicio. La palabra os doy aquí Dioses, que puesto en Micenas, que vuestras aras sean llenas de reses muertas por mi. Ofrendareos mis tesoros, 
matareos cien corderos, cien ovejas, cien carneros, cien puercas, y más cien toros.

Tal vez la tragedia más perfecta sea La muerte de Virginia y Apio Claudio ${ }^{17}$, o, como decía Moratín, la «menos mala». En este caso las fuentes clásicas son, principalmente, el libro III de Tito Livio, pero también las Antiquitates romanae de Dionisio de Halicarnaso. Importante fuente posterior es el De claris mulieribus de Boccaccio.

Cueva plantea el asunto desarrollando el interrogante que presenta las relaciones de una mujer casta e íntegra de carácter y un viejo atormentado por la fuerza irresistible del amor, que actúa sobre él como un fatum superior. La fuerza de la obra reside en la reacción de Virginia: es una obra de rebelión contra lo invencible, lo que lleva a una solución heroica, la muerte de la joven a manos de su propio padre, que se produce en el acto tercero, con lo que el cuarto queda reservado, exclusivamente, para la venganza contra Apio Claudio. Se demuestra nuevamente, como en Los siete infantes de Lara, que la temática de la venganza es o la base misma de la dinámica de la tragedia o bien el complemento indispensable de su realización dramática.

Tampoco aquí se respetan las unidades: la obra se desarrolla en Roma y Algido, con una duración de unos pocos días, y a la acción principal se suma la de la venganza. El personaje de Virginia presenta rasgos bien definidos, destacando sobre todo la honestidad, piedra de toque de toda la desgracia (Icaza 1917, p.II, 85):

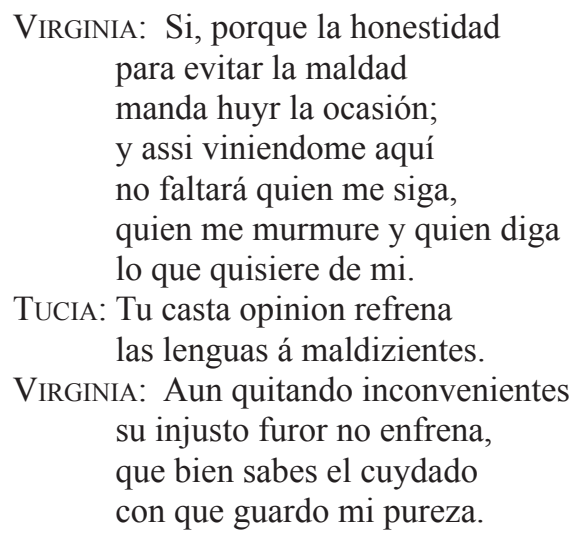

Bien es cierto que su honestidad va acompañada de un destacado espíritu religioso que, a pesar del respeto mostrado en todo momento por las divinidades clásicas, deja entrever algunos rasgos de cristianismo (Icaza 1917, p.II, 93):

\section{VIRGINIA: ¿Oy me dices, Tucia mía que hazen solenne fiesta}

\footnotetext{
${ }^{17}$ Para el tema de Virginia (la mujer, la castidad, el honor y la violencia), $c f$. los trabajos de R. Walthaus (1993) y (1996).
} 
a la teucra y pura Vesta?

TuCiA: Sí, señora, oy es el día.

VIRGINIA: ¿Qué quieres tu que hagamos?

Tucia: Eso queda a tu elecion

pues le tienes devocion.

Su papel, en realidad, es pasivo, de resistencia, es una heroína que no se suicida, sino que es su padre Virginio quien la mata, con lo cual la protagonista no puede alcanzar el brillo de, por ejemplo, Dido o Lucrecia.

El antagonista es Apio Claudio, que a veces habla con gran altura trágica y a veces con deleznable bajeza. Personaje atormentado, arrastrado por su destino, el amor y la pasión, que le harán suicidarse al final de la obra con saña por no haber podido saciar su apetito (Icaza 1917, pp.II, 80-81):

APIO: Bien se que potestad ni fortaleza pueden nada contigo y que desnudo domas de los leones la braveza, bien se que del gran Iupiter no pudo la ira ardiente domeñar tu saña, ni de Marte la espada y fuerte escudo; ...

¿Que gloria as conseguido, que provecho, que triunfo, que renombre, que corona, de poner mi vegez en tal estrecho?

El tercer personaje es Virginio, el padre de la joven, a quien Cueva pinta como arrogante e impetuoso, tremendamente enérgico en todos sus sentimientos. Su presencia en los actos tercero y cuarto nos lleva de su presentación al intento de arreglo pacífico y, finalmente, a la solución heroica (Icaza 1917, pp.II, 117; 119 y 119):

VIRGINIO: Capitan soy de Roma, só elegido

para del enemigo defendella,

Roma, a quien yo defiendo, me defienda, porque a su capitan este no ofenda.

...

Suplicote, Appio Claudio, no permitas

tal injusticia; mira y considera

que al padre y al esposo se la quitas

y la hazes de libre prisionera.

...

¡No será tal! ¡Desviate enemigo!

Roma quiero y que todo el mundo entienda

de tu injusticia la crueldad estraña,

que tu maldad y mi razon se estienda

en quanto el sol alumbra y el mar baña;

y porque de Virginio no se ofenda 
la gloria, dara vida a mi hazaña con quitarte la tuya jo hija amada! pues no serás muriendo deshonrada. ¡Esta inocente sangre pida al cielo justicia, y al consagro con tu vida, pida vengança alla, pues en el suelo faltó justicia de quien fuesse oyda!

Si se tiene en cuenta la monstruosidad y exceso de la solución adoptada, que lleva a considerar honra la decisión del asesinato de su propia hija (en un tema, el del honor vengado, poco frecuente en el teatro prelopesco), puede concluirse que se trataría de presentar en escena acciones desmesuradas para poner de relieve la alienante ley que gobernaba los conflictos de honor.

Puede considerarse la obra una reconstrucción arqueológica de la leyenda de Virginia que sigue el plan de la fuente latina (Livio), en la que aparecen ya los personajes, y mantiene cierto color clásico en las referencias a antiguas instituciones políticas y administrativas romanas (decénviros, senado, edil) y referencias religiosas propias de la Antigüedad. En el episodio narrado por Livio se aprecian como componentes básicos uno político (tiranía y abuso del decemuir), otro novelesco-sentimental (la pasión) y otro judicial (falsos pleitos tramados por Apio para poseer a Virginia). En el relato latino son el primero y el tercero los que pasan a primer plano, mientras que Juan de la Cueva concentra su tragedia en el segundo y el tercero. Para Livio la leyenda de Virginia era importante como historia etiológica de tipo sentimental que fundamenta el cambio político en Roma y la expulsión de los decemuiri. El sevillano, por su parte, reduce la dimensión política al eliminar tanto las protestas que denuncian la tiranía y abusos políticos de Apio Claudio como la rebelión política. Conserva, sí, el fuerte componente judicial pasando el tema del honor al primer plano y amplificando el papel de la mujer ${ }^{18}$ : es un modelo de pudor frente a los intentos de seducción de Apio Claudio; muchacha educada en los altos principios morales que caracterizaban a su padre, y que recuerda a Livio (3.44.2-4):

Pater uirginis, L. Verginius, honestum ordinem in Algido ducebat, uir exempli recti domi militiaeque. Perinde uxor instituta fuerat liberique instituebantur. (...) Hanc uirginem adultam, forma excellentem Appius amore amens pretio ac spe perlicere adortus, postquam omnia pudore saepta animaduertit, ad crudelem superbamque uim animum conuertit.

Se presenta, pues, una concepción plenamente patriarcal del honor: el honor como piedra angular del orden público y como responsabilidad exclusiva del hombre.

La última de las tragedias, la Tragedia del Príncipe tirano, no es de tema clásico, pero ofrece notables reminiscencias y presencias, como por ejemplo el reino de Col-

\footnotetext{
${ }^{18} \mathrm{Cf}$. para la imagen de la mujer fuerte cuya virtud es como una roca (la virago, personaje del gusto de Cueva), el trabajo de R. Walthaus (1993).
} 
cos, en el que las mujeres serán las únicas valientes que pondrán fin a la maldad ${ }^{19}$. Es en realidad la segunda parte de la que el autor llamó Comedia del Príncipe tirano, comedia simplemente porque el tirano no acaba muriendo en la primera parte. El príncipe Licímaco es un personaje de pesadilla que comete los crímenes más crueles y cuya demencia apenas tiene parangón en el teatro español. Lo tremendo de este personaje es la ausencia de finalidad en todos sus actos, la absoluta gratuidad de todos ellos. Cuando uno de los personajes, horrorizado por lo que acaba de hacer, le pregunta: «¿Qué te movió a hacer maldad tan fiera?», responde: «¿Qué ha de moverme más que ser mi gusto y querer yo quel mundo todo muera?». Y lo llamativo es que Juan de la Cueva, y en eso sí es distinto de sus coetáneos, adopta ante los crímenes de sus personajes una actitud impasible, libre de toda valoración moral, como si ésta no rigiera o no fuera necesaria en el universo del drama ${ }^{20}$.

La acción tiene lugar en la lejana y mítica Colcos. En la comedia, el Rey de Colcos, Agelao, que tiene dos hijos, la princesa Eliodora y el joven príncipe Licímaco, pretende casar a su hija, heredera del trono, con el Rey de Lidia y así unir los dos reinos. Pero Licímaco, soberbio, violento y sediento de poder, no acepta la decisión y sigue el consejo de Tracildoro de asesinar a su hermana, matándolo después a él mismo. Todo sucede en secreto. Al Rey, desesperado por la desaparición de su hija, se le presentan dos sombras, las de los muertos, que le refieren los asesinatos. Manda a su hijo a prisión, lo condena a muerte pero conseguirá escapar con la ayuda de un grande del reino. Otros miembros de la Corte interceden ante el Rey que acepta nuevamente a su hijo y le promete el reino. Concluye así la comedia.

En la tragedia, el Príncipe, tras hacer profesión de su fe política y expresar su deseo de conquistar el mundo, consigue que el padre abdique y le otorgue la corona. El Rey da muestras de cómo se debe administrar la justicia, mientras en la Corte suceden hechos cargados de turbadoras señales: un mudo se presenta con un libro y una hoz en la mano, se rasga el vestido, rompe el libro y se degüella con la hoz, dejando a todos perplejos sin entender el significado del suicidio. Tras una serie de terribles episodios, el Rey se dispone a proceder a la ceremonia de abdicación y juramento del Príncipe, pero hay un nuevo presagio: aparece la figura del Reyno, un hombre con el pecho atravesado por una espada que representa la situación de Colcos, que explica, además, la aparición del mudo: es la desastrosa condición de la patria, el libro roto el desprecio a las leyes, mientras que el suicidio indicaba que alguien pagaría con la muerte esos males. Todo ocurrirá así. Además, Licímaco, llevado de una malsana pasión, quiere poseer a Teodosia y a Doriclea. La serie de crímenes tomará un ritmo vertiginoso. Entre los episodios más crueles, Licímaco ordena un banquete y ante la mesa manda enterrar hasta el pecho al marido de Teodosia y al padre de Doriclea,

\footnotetext{
${ }^{19}$ De este reino se dice en la segunda parte de La araucana, Canto XXVII: «Mira el reino de Colcos, tan famoso / por la isla nombrada de Medea, / adonde el trabajado Jasón vino / en busca del dorado vellocino».

${ }^{20}$ En el motivo del tirano ve E. del Río (1992: 403-406) ecos de Phoenissae, Oedipus e, incluso, del Hercules furens. Pero insiste (1992: 406-408) en que el Príncipe tirano guarda especial relación con Thyestes, la más «horrible» de las tragedias de Séneca.
} 
obligando a ambas a participar en él. Luego son llevadas a los aposentos de Licímaco, mientras él ordena que se preparen unos perros feroces para que acaben con los enterrados. En la habitación encontrará la muerte a manos de las dos mujeres.

El mayor reproche que se le ha hecho es la inverosimilitud de la fábula y el exceso que caracteriza a los personajes. Sin necesidad de ver en el Príncipe y en su padre un reflejo del príncipe don Carlos y su padre Felipe II, como hace Watson (1971), sí se pueden descodificar, comedia y tragedia, como un gigantesco grito de protesta contra el abuso de poder. La obra puede ser una expresión más del malestar existente en la España filipina. Tan pronto como murió Felipe II desapareció del teatro la insistente figura del tirano aborrecible.

Este Príncipe creado por Cueva es un ser que no puede tener paralelo en la realidad. El autor se propuso crear un monstruo, y lo consiguió, pero así se perdió el fin aparentemente moralizador de la obra, porque nunca puede el espectador conmoverse ante algo extraño a su naturaleza. La condición que exigían los griegos al héroe trágico de no ser ni bueno ni malo fue olvidada completamente por Juan de la Cueva. Veamos un simple ejemplo de la anormalidad del personaje (Icaza 1917, 2, p.212):

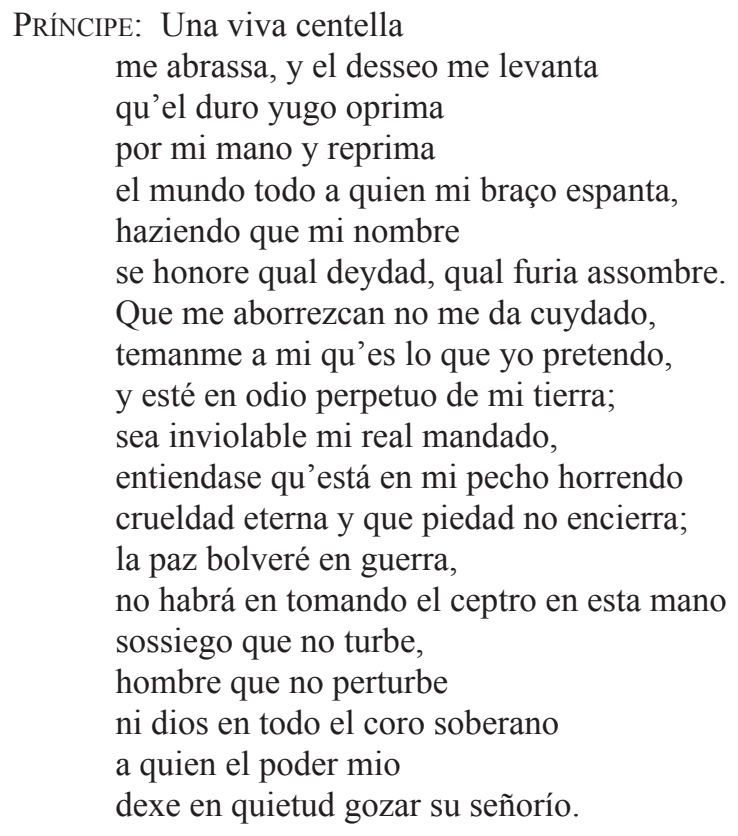

Mandará quemar el templo de Marte y todos los documentos fueros y libertades ciudadanas, encargo que asumirá Ligurino (Icaza 1917, p.II, 236); se proclama objeto de adoración para sus súbditos (Icaza 1917, p.II, 243); desprecia a los dioses (Icaza 1917, p.II, 266):

PRÍNCIPE: Cuéntame de qué modo fue cumplido mi mando, si excediste o traspasaste 
de lo que te fue en esto cometido.

Ligurino: Fui a los Archivos, cual, Señor, mandaste, del gran templo de Marte, y con violencia

los abrí de la suerte que ordenaste.

Tomé todos los libros, y en presencia del pueblo, que ya junto me cercava, alterado en confusa competencia, $\mathrm{y}$ al fuego ardiente ante sus ojos dava las exenciones, libertades, fueros y sus franquezas en la llama echava ...

No paró aquí el estrago lamentable, que la ligera llama con crueza hizo otro no menos.

\section{PRÍNCIPE: Agradable.}

Ligurino: Que yendo, qual te digo, en su braveza, llena de horror, los techos abrasando, abrasó el burgo, gente y fortaleza.

...

PRÍNCIPE: Entienda el mundo que á de ser mi nombre no menos que deydad reverenciado, y qu'en qualquiera parte que se nombre an de temer como de Iove ayrado. ...

Y al Retor summo del celesto impero con los mas dioses lançaré a la tierra.

Frente a este personaje, Cueva opone otros tres que personifican las virtudes contrarias: el Rey, Doriclea y Teodosia, con ese nombre parlante que significa «la que ha sido dada como regalo de dios»».

Merece comentario especial la aparición de elementos fantásticos. Todos los compenentes extrahumanos vienen a concretarse en dos figuras alegóricas de suma importancia: el Mudo y el Reyno de Colcos, desdoblamiento escénico de una misma figura, la auténtica víctima de la tiranía del Príncipe, el «reino mudo» que ha perdido sus fueros y libertades. Desde el punto de vista simbólico, la mudez representa los primeros estadios de la creación, regresión a ellos. Por eso aluden con frecuencia las leyendas a la mudez como castigo por graves males cometidos (que determinan por sí mismos la regresión).

Cueva mezcla elementos clásicos y medievales introduciendo momentos de movimiento y ritmo líricos, como ocurre, por ejemplo, en la comedia, en cuyo primer acto las Parcas, en un ángulo del escenario, tejen la tela de la vida de la princesa Eleonora y cortan el hilo en el momento mismo en que Licímaco la asesina, representación simbólica de lo que ocurre contemporáneamente en otra parte del escenario. En estas obras todo es atropellado, inconsecuente, inverosímil, imposible, horrendo, en suma, ajeno al teatro. 
De entre las comedias que se han clasificado como de asunto novelesco destaca $E l$ infamador, considerada como la más interesante de la producción dramática de Juan de la Cueva. Suele afirmarse que si hubiera prescindido de la intervención de seres mitológicos como Némesis, Diana, Venus, Morfeo, claramente desplazados e inoportunos en el ambiente realista de la pieza, no cabe duda de que hubiera creado una obra realmente interesante, muy cercana a la comedia del siglo XVII por sus personajes de carne y hueso, sus lances amorosos, el dinamismo de la acción y el dibujo de las costumbres urbanas. Esa mezcla heterogénea de dos mundos dramáticamente contradictorios, difícilmente armonizables, muestran lo alejado que aún estaba nuestro autor del arte nuevo que Lope instaura. Lo cierto es que es una farsa mitológica, sin época ni ambiente nacional. Su fama se acrecentó, sin duda, gracias a la arbitraria opinión de que el personaje de Leucino sería el modelo primitivo de El Burlador de Sevilla de Tirso, y del Don Juan Tenorio de Zorrilla. En realidad, el tal personaje no es más que un difamador, un rico y necio fanfarrón, joven galanteador, que nada, o muy poco, tiene que ver con el perfil del Don Juan. Pretende el amor de Eliodora, que no le corresponde, y ello le lleva a forzarla con la ayuda de Ortelio, criado del propio Leucino. Eliodora mata a Ortelio y es acusada y difamada por Leucino, pero será liberada después de aclararse los hechos. Leucino y otro cómplice serán condenados a muerte y ejecutados.

Es digno de recordar a propósito de la tradición clásica el enfrentamiento entre las tres diosas, Némesis, Diana y Venus, así como la presencia del dios del Sueño, de la Justicia, de Morfeo como ministro del sueño, del río Betis y de los salvajes Hipodauro y Demolión. Las referencias clásicas, por tanto, aparecen por doquier; aparte los personajes, hay indicaciones geográficas, otras divinidades y comparaciones a partir de hechos de la Antigüedad, como la guerra de Troya. Sirva de ejemplo un texto, correspondiente al principio de la cuarta jornada, en el que Hircano, padre de Eliodora, decide dar muerte a su hija en la cárcel (vv. IV 18-29):

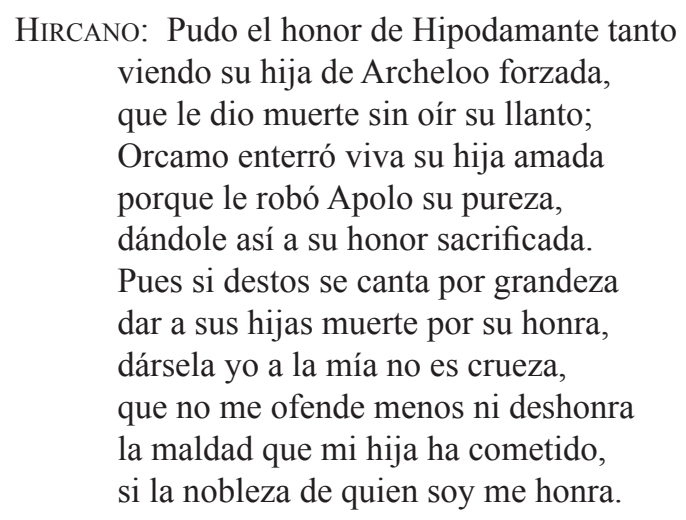

Para finalizar este recorrido, mencionaremos la única comedia de tema puramente clásico, de historia romana, La libertad de Roma por Mucio Cévola. Cayo Mucio Escévola fue el héroe romano que intentó asesinar a Porsena, último de los monarcas etruscos, cuando atacó Roma en el 509 a.C. Escévola se adentró en la tienda de Porsena, 
pero asesinó a su ayudante por error. Fue capturado y confesó ante el tribunal del Rey que él era el primero de los trescientos jóvenes romanos que se habían propuesto como objetivo dar muerte a Porsena. A pesar de ser amenazado con la tortura y la muerte si no revelaba toda la conspiración, Escévola introdujo su mano derecha en el fuego de un altar y la mantuvo allí hasta que se consumió. Su valor impresionó tanto a Porsena que el prisionero fue puesto en libertad y el Rey etrusco hizo la paz con Roma. De las cuatro jornadas de la comedia, se afirma que sobran las tres primeras, de suerte que la aparición del dios Quirino, las furias, el desafío de Espurio y Bruto, la operación de cortar a Sulpicio, coram populo, las orejas, una mano y la nariz, su muerte, la quema de su cuerpo, la conservación de sus cenizas en una urna de oro, los viajes del rey Tarquinio y aun su existencia, todo esto, sería inútil. Mucio Escévola, protagonista de la obra, no aparece hasta la última jornada y en ella, necesariamente, ha de precipitarse la acción y concluir. El estilo, nuevamente, va de lo ampuloso a lo desaliñado y ridículo.

\section{A MODO DE CONCLUSIÓN}

Juan de la Cueva, que desde su niñez tradujo a los clásicos latinos y era italizanizante fervoroso en su mocedad, pasada ésta lo fue mucho menos que la mayoría de sus contemporáneos y de sus inmediatos sucesores. Mientras aquellos iban a Italia y tomaban del Renacimiento italiano lo mejor y más amplio, que estaba en el ambiente y no en los libros, Cueva pasó a América, lo que produjo algunos versos curiosos y valiosos por la verdad de los elementos históricos en ellos conservados y poetizados algo más que mediocremente, pero restó a su cultura las enseñanzas que mejor influyeron en otros ingenios de entonces (Icaza 1973, p.XLIX).

Como dramaturgo, es un caso más de incertidumbre y titubeos en aquella etapa de transición que intuía las nuevas formas del arte escénico nacional, sin acertar a desprenderse de la herencia clásica. El teatro de Juan de la Cueva está lleno de invenciones que, con frecuencia, llevan la inverosimilitud y la inconsecuencia a la estructura narrativa. Y la abundancia de personajes, gestos y acciones de hipertrofiada violencia no llegan a integrarse de forma justificada. Valga recordar en este punto que lo trágico presupone una autoridad sobrenatural: sin un sentido trascendental de la existencia no hay tragedia; la ineluctabilidad y la importancia del elemento divino, sobrenatural, son consustanciales a lo trágico. Lo que ocurre es que lo trágico y lo doloroso se suelen superponer, pero hay que recordar que no todo lo doloroso es trágico. Cueva nos presenta un concepto de tragedia radicalmente diferente al clásico, como es lógico por otra parte para una sociedad que carece del sentido real de la «tragicidad». El lenguaje dramático es, como sus personajes, otro signo marcado por la abundancia y la hipertrofia. La pompa y la altisonancia, que resultan a veces inadecuadas para el personaje que las utiliza, lo mismo se ponen en boca de reyes que de villanos, rompiendo así el decoro y la verosimilitud defendidos por el teatro tradicional, aunque abren la puerta a la mezcla de lenguajes «altos» $\mathrm{y}$ «bajos» tan presentes en la Comedia Nueva. En todo caso, uno de los mejores conocedores del teatro sevillano de aquellos tiempos, Jean Sentaurens 
(1984), llega a afirmar que su lenguaje dramático es la confirmación del carácter insoportable de sus obras para el público de la época. Sin embargo, la obra dramática del sevillano tiene unos valores propios de la transición y, sobre todo, una dimensión muy considerable para medir la importancia socio-política del gesto dramático.

Juan de la Cueva se yergue ante nosotros en la encrucijada de todos los caminos del arte dramático de su tiempo, pero sin genio suficiente para abrir la puerta que, tal vez, adivinaba. Terminemos con unas palabras de F. Ruiz Ramón (2000, p.113): «En un imaginario museo del teatro su estatua debería ser colocada en el umbral que separa y une lo antiguo y lo nuevo. Llevaría una venda en los ojos y tendría las manos tendidas hacia el futuro».

\section{REFERENCIAS BIBLIOGRÁFICAS}

Armas, F. De - García Lorenzo, L. - García Santo-Tomás, E. (eds.) (2008), Hacia la tragedia áurea: lecturas para un nuevo milenio, Madrid - Fráncfort, Iberoamericana - Vervuert. ARrónIZ, O. (1977), Teatros y escenarios del Siglo de Oro, Madrid, Gredos.

Bataillon, M. (1935), «Simples réflexions sur Juan de la Cueva», Bulletin Hispanique 37, 329-336 [= (1964), «Unas reflexiones sobre Juan de la Cueva», en Varia lección de clásicos españoles, Madrid, Gredos, pp.206-213].

BLÜHER, K.A. (1983), Séneca en España. Investigaciones sobre la recepción de Séneca en España desde el siglo XIII hasta el siglo XVII, Madrid, Gredos.

CANET VALLÉs, J.L. (1997), «El nacimiento de una nueva profesión: los autores/representantes, 1540-1560», Edad de Oro 16, 109-120.

Carballo Picazo, A. (ed.) (1953), A. López Pinciano. Philosophia antigua poética, 3 vols., Madrid, CSIC.

Cebrián García, J. (1984), Juan de la Cueva. Fábulas Mitológicas y Épica Burlesca, Madrid, Editora Nacional.

Cebrián García, J. (1986), La fábula de Marte y Venus de Juan de la Cueva. Significación y sentido, Sevilla, Universidad de Sevilla.

Cebrián García, J. (1991), Estudios sobre Juan de la Cueva, Sevilla, Universidad de Sevilla.

Crawford, J.P.W. (1937), Spanish Drama before Lope de Vega, Filadelfia, University of Pennsylvania Press.

Froldi, R. (1968), Lope de Vega y la formación de la comedia, Salamanca, Anaya.

Froldi, R. (1999), «Reconsiderando el teatro de Juan de la Cueva», en PedrazA, F.B. - GoNZÁlez CAÑAL, R. (coords.), El teatro en tiempos de Felipe II: Actas de las XXI Jornadas de teatro clásico (Almagro, 7, 8 y 9 de julio de 1998), Almagro, Universidad de CastillaLa Mancha.

GARCÍA Soriano, J. (1945), El teatro universitario y humanístco en España. Estudios sobre el origen de nuestro arte dramático; con documentos, textos inéditos y un catálogo de antiguas comedias escolares, Toledo, Tipografía de R. Gómez Menor.

GlenN, R.F. (1973), Juan de la Cueva, Nueva York, Twayne.

HeRMENEGiLdo, A. (1961), Los trágicos españoles del siglo XVI, Madrid, Fundación Universitaria Española. 
Hermenegildo, A. (1973), La tragedia en el Renacimiento español, Barcelona, Planeta.

Hermenegildo, A. (1994), El teatro del siglo XVI, Madrid, Júcar.

Hermenegildo, A. (2003), «La tragedia: de Pérez de Oliva a Juan de la Cueva», en Huerta, J. (dir.), Historia del teatro español. I. de la Edad Media a los siglos de oro, Madrid, Gredos, pp.475-499.

ICAZA, F.A. DE (ed.) (1917), Juan de la Cueva. Comedias y tragedias, 2 vols., Madrid, Sociedad de Bibliófilos Españoles.

ICAZA, F.A. DE (ed.) (1973), Juan de la Cueva. El infamador. Los siete infantes de Lara. Ejemplar poético, Madrid, Espasa Calpe.

Lauer, R. (1987), Tyrannicide and Drama. Part I. The Tradition of Tyrannicide from Polibius to Suárez. Part II. The Tyrannicide Drama in Spain from 1579 to 1698, Stuttgart, Franz Steiner Verlag.

Ly, N. (1983), «El lenguaje del horror en el teatro de Juan de la Cueva», Criticón 23, 65-85.

Morby, E.S. (1937), «The Influence of Seneca's Tragedy in the plays of Juan de la Cueva», Studies in Philology 34, 83-391.

Morby, E.S. (1940), «Notes on Juan de la Cueva: Versification and Dramatic Theory», Hispanic Review 8, 213-218.

Reyes Cano, J.Ma (1980), La poesía lírica de Juan de la Cueva. Análisis de la edición de las 'Obras'(1582), Sevilla, Diputación Provincial.

Reyes PeÑA, M. DE Los (1980), «El teatro prelopesco», en Rico, F. (dir.), LóPez EstradA, F. (ed.), Historia y crítica de la literatura española. II. Siglos de Oro: Renacimiento, Barcelona, Crítica, pp.540-552.

Río, E. DEL (1992), La influencia del teatro de Séneca en la literatura española, Tesis doctoral UCM, Madrid (=Logroño, Universidad de La Rioja, 1995, Microforma).

Rodríguez Marín, F. (1923), Nuevos datos para las biografías de cien escritores de los siglos XVI y XVII, Madrid, Tipografía de la Revista de Archivos, Bibliotecas y Museos.

Ruiz RAmón, F. (2000), Historia del teatro español (desde sus orígenes hasta 1900), $10^{\mathrm{a}}$ edición, Madrid, Cátedra.

Sentaurens, J. (1984), Seville et le théâtre de la fin du Moyen Âge à la fin du XVII ème siècle, Burdeos, Presses Universitaires.

Valbuena Prat, A. (1956), Historia del teatro español, Barcelona, Noguer.

Walthaus, R. (1993), «Entre Diana y Venus: mujeres castas y mujeres fatales en el teatro de Juan de la Cueva y Cristóbal de Virués»», en Walthaus, R. (ed.), La mujer en la literatura hispánica de la Edad Media y el Siglo de Oro, Amsterdam-Atlanta, Rodopi, pp.71-90.

Walthaus, R. (1996), «Mujer, honor y violencia: el tema de Virginia en el drama español del Siglo de Oro», en Arellano, I. - Pinillos, Mac. - Serralta, F. - Vitse, M. (eds.), Studia Aurea. Actas del III Congreso de la Asociación Internacional 'Siglo de Oro', PamplonaToulouse, Griso-Lemso, vol. II. Teatro, pp.423-428.

Wardropper, B.W. (1955), «Juan de la Cueva y el drama histórico», Nueva Revista de Filología Hispánica 9, 149-156.

WARdropper, B.W. (1980), «Humanismo y teatro nacional en Juan de la Cueva», en Rico, F. (dir.), López EstradA, F. (ed.), Historia y crítica de la literatura española. II. Siglos de Oro: Renacimiento, Barcelona, Crítica, pp.586-590.

Watson, A. (1971), Juan de la Cueva and the Portuguese Succession, Londres, Tamesis. 